\title{
The fanciful optimism of Miguel Sánchez-Mazas. Let us calculate... $=$ Freedom and Justice
}

\author{
(El optimismo soñador de Miguel Sánchez-Mazas. \\ Calculemos... = Libertad $y$ Justicia $)$
}

\author{
Javier De LORENZO*, Andoni IbarRa \\ ${ }^{1}$ University of Valladolid \\ ${ }^{2}$ University of the Basque Country (UPV/EHU)
}

\begin{abstract}
May 2020 marked the $25^{\text {th }}$ anniversary of the death of Miguel Sánchez-Mazas, founder of Theoria. An International Journal of Theory, History and Foundations of Science, and regarded as the person who brought mathematical logic to Spain. Here we present some of his biographical features and a summary of his contributions, from his early work in the 1950s - introducing contemporary advances in logic and philosophy of science in a philosophically backward milieu dominated by the scholasticism of that era in Spain - to the development of a project of Lebnizian lineage aimed at producing an arithmetic calculation that would elude some of the difficulties confronting Leibniz's calculus.
\end{abstract}

KEYWORDS: Miguel Sánchez-Mazas, Leibniz, numerical characteristic, calculation of norms, jurisprudence.

RESUMEN: En mayo de 2020 se cumplen 25 años del fallecimiento de Miguel Sánchez-Mazas, fundador de Theoria. An International Journal of Theory, History and Foundations of Science $y$ considerado como el introductor de la lógica matemática en España. En esta contribución presentamos algunos sus rasgos biográficos, así como un resumen de sus aportaciones, desde las iniciales en la década de los cincuenta del siglo XX - introduciendo los avances en lógica y filosofia de la ciencia contemporáneos en un medio filosóficamente retrasado como el dominado por la escolástica de aquel tiempo en España - hasta el desarrollo de un proyecto de estirpe lebniziana orientado a elaborar un cálculo aritmético que eludiera algunos de los problemas con los que se vio confrontado el calculo de Leibniz.

PALABRAS CLAVE: Miguel Sánchez-Mazas, Leibniz, caracteristica numérica, cálculo de normas, jurisprudencia.

* Correspondence to: Javier de Lorenzo. - javierdelor@gmail.com

How to cite: De Lorenzo, Javier; Ibarra, Andoni (2020). "The fanciful optimism of Miguel Sánchez-Mazas. Let us calculate... = Freedom and Justicen; Theoria. An International Journal for Theory, History and Foundations of Science, 35(3), 255-265. (https://doi.org/10.1387/ theoria.21922).

Received: 17 July, 2020; Final version: 30 August, 2020.

ISSN 0495-4548 - eISSN 2171-679X / (C) 2020 UPV/EHU 


\section{Introduction}

This year marks the $25^{\text {th }}$ anniversary of the death of Miguel Sánchez-Mazas, who was founder of Theoria - An International Journal of Theory, History and Foundations of Science, and its editor-in-chief in its initial stages, from 1952 to 1956, and when it was later reestablished in 1985, until Sánchez-Mazas' death on May 6, 1995 in Donostia-San Sebastian.

Miguel Sánchez-Mazas was a victim of numerous injustices, as Carlos París (1996) recalled, but always confronted them with total optimism. Such optimism was evident both in his personal, private life and in his investigative and political attitude. It was this optimism that led him to address an issue relating to mathematical logic - the search for a universal numerical characteristic with an intensional approach, which was considered resolved and thus excluded from mainstream logic at the time when he began his work. It was linked, in a sense, to both Leibniz's and Frege's impossible dream. For Leibniz, Reasoning was identified with Let us Calculate; for Frege, Reasoning equated to Deduction.

This contribution begins, in the following section, by presenting some biographical features of Sánchez-Mazas' political and social commitment to justice and freedom, which would later drive him into political exile. Section 3 presents a summary of Sánchez-Mazas' organizational-institutional and research activities at the intersection between the fields of logic, mathematics and law. Section 4 concludes with a critical assessment of his project to develop a numerical calculation, and its main results.

\section{Freedom and justice; horizons of committed scientific action}

Son of the writer Rafael Sánchez Mazas and Italian Liliana Ferlosio, Sánchez-Mazas was born in Peschiera del Garda, Verona, Italy, on September 3, 1925. His father was one of the founders of the Spanish Falange in 1933, a political party created in the image of Mussolini's Fascio. Rafael Sánchez had been a correspondent for the Spanish newspaper $A B C$ in Italy from 1922 to 1929 and aligned himself with Italian Fascist thinking. He was a minister without portfolio in the first government headed by the dictator Franco (1939-40).

Miguel Sánchez-Mazas grew up in a culturally diverse family environment. He had two brothers, Rafael Sánchez Ferlosio (1927-2019), regarded as one of the foremost writers in Spanish in the latter half of the 20th century, and Chicho Sánchez Ferlosio (1940-2003), an anti-Franco singer-songwriter who gained popularity in the 1960 s and 70 s. His sister, Gabriela, actively participated in the initial manifestations of the feminist struggle in the 1960s and married Javier Pradera, a leading actor in the Spanish "transition" to a representative democracy after Franco's death in 1975.

Having been brought up as a young Falangist, Miguel soon found himself politically at odds with his father's ideology, with whom he disagreed politically but maintained a good relationship ${ }^{1}$. From a Catholic standpoint and driven by social concerns, in 1947 he signed the first student "manifesto" in the form of a call to the Spanish youth demanding the first

1 We would like to highlight the biographical information provided by María Luisa Cutanda, Miguel Sánchez-Mazas' widow, who, alongside him, founded Theoria in its initial stages (Cutanda 2019). 
post-war generation's right to criticize the Franco regime. In 1956, together with a group of university students from bourgeois families and some of the children of collaborators with the dictatorship, he published a Manifesto calling for a National Congress of Students to debate the opening-up of universities in complete freedom. When the Manifesto was published it provoked a wave of repression and arrests, including Sánchez-Mazas' arrest. Facing the difficulties in continuing his scientific work at the CSIC (Spanish High Council for Scientific Research, the leading research institution in Spain), he traveled with his family to Geneva, where he would eventually become a political refugee, having been sentenced in absentia to a 12-year prison term by Franco's courts in 1967 for the publication of several articles.

For more than two decades, until his return to Spain in 1981, Sánchez-Mazas carried out extensive political activity in the PSOE (Spanish Socialist Workers' Party) and trade union activity in the UGT (General Workers' Union). He not only promoted the local branches of both organizations but also engaged in the design and renewal of socialist policies in response to the leaderships associated with the Republican exile during the civil war (1936-39). In addition to helping to set up local associations and organizations (universities, trade unions,...), he promoted various publications related to these fields in Switzerland (Información Social Española, El Obrero Español, The internal UGT newsletter for the Zurich branch, etc).

His planned return to the university in Spain in 1978 was prevented by the veto the "democratic" transition authorities imposed on five academics, including Sánchez-Mazas, to join the university (París 1996) ${ }^{2}$. Rector Gregorio Monreal then offered him the chance to join the recently inaugurated Faculty of Philosophy at the University of the Basque Country (1981). His last fifteen years at this university were particularly prolific in terms of scientific results, and fruitful with regard to the institutional and organizational renewal projects in which Sánchez-Mazas was involved as one of the leading philosophical figures in the new faculty. This was made possible, in part, by the fact that he distanced himself from the political front line: he viewed the rampant economic and political corruption within the PSOE in the late 1980s with sadness and astonishment, and rapidly dissociated himself from the emotional commitment that continued to bind him.

\section{From mathematical logic to computing and law: theoria cum praxi}

This journey of political and trade union commitment outlined in the previous section was inseparable from his interest and struggle for a fairer and freer world. Both tendencies in his scientific orientation were seen as logical.

Sánchez-Mazas began his studies in Rome and then, in Madrid, graduated in "Exact Sciences" (Mathematics), which he combined with his studies in Philosophy so that he could, he would often jest, be closer to who would later become his wife, María Luisa Cutanda. The fact is that Mathematics and Philosophy were to become the two domains

2 The Council of Spanish University Rectors vetoed 5 academics because of their left-wing political background: Miguel Sánchez-Mazas, Manuel Castells — current Minister of Universities-, Carlos Castilla del Pino, Manuel Sacristán and José Vidal. 
that, throughout his teaching and research life, would modulate a rigorous program of radically interdisciplinary interest on the fringes of philosophy, mathematical logic and law.

At first, having just graduated, the design of this program was completely new in $1950 \mathrm{~s}$ Spain. With the founding of the Philosophy and History of Science Section (later Department) at the Luis Vives Institute in the CSIC in the early 1950s, a group of young and enthusiastic developers attempted, as Sánchez-Mazas recalled,

...to develop, as far as possible, information, documentation, research and teaching in Spain in areas that were at that time so neglected, if not harassed by suspicion, on the part of the official culture, such as mathematical logic, epistemology and philosophy, methodology and history of science, conceived in a modern, open and critical way. (Sánchez-Mazas 1987, 242)

The group was brilliant and included some of the philosophers who, from the 1960s onwards, would renew Spanish philosophy: Carlos París, Gustavo Bueno, Luis Martín Santos, Victor Sánchez de Zavala, Francisco Pérez Navarro, Enrique García Camarero, Norman Barraclough, Raimundo Drudis-Baldrich, and others. The group featured Miguel Sánchez-Mazas who, acting as Department Secretary, was the group's most prominent animator. The group also enjoyed the prestigious support of the most renowned mathematician of the time, Julio Rey Pastor (Head of the Department), the physicist Julio Palacios, the physician Pedro Laín Entralgo, and of philosophers such as: Jaime Echarri, Faustino Cordón and, from exile, Juan David García Bacca and José Ferrater Mora, among others.

The activities developed by this group were numerous in the period 1952-56, many of which were directly inspired and promoted by Sánchez-Mazas. These include: founding the Spanish Society of Epistemology and History of Science (the Spanish branch of the current Division of Logic, Philosophy and Methodology of Science at the International Union of History and Philosophy of Science); creating the Mathematical Logic Seminar within the Luis Vives Institute, whose secretary was also Sánchez-Mazas; publishing articles and monographs, known as "Cuadernos"(Notebooks), by both the Department and Mathematical Logic Seminar; and, above all, the publication of Theoria - Journal of Theory, History and Foundations of Science, which, through reviews and critical discussion, enabled new currents of philosophical thought to be introduced in Spain.

The activities mentioned fostered the awareness and dissemination of works by Carnap, von Juhos, Bell, and others. The journal, run by Sánchez-Mazas from its outset (Ronzón 1982-83), analyzed works by Wittgenstein, Quine, Russell, etc. From 1954 onwards, it set out to address specific issues concerning mathematical logic in a new section included to this end, and whose presentation in issue 7-8 denoted the philosophical climate of the time. Having noted the existence "in all cultured countries" of prestigious journals devoted to logic, Sánchez-Mazas regretted the fact that

...in Spain, where so many journals on Philosophy are published, especially on scholasticism just think about the sheer number of them, published by the different orders and religious congregations-, there is no journal on Logic. I find this is odd, since far more limited specialties with a far less central role in science have found their niche among the countless publications of the Spanish National Research Council. Meanwhile, more technical and rigorous logical research, which requires appropriate symbolism, has not tended to find its way into general philosophical journals because, for the overly traditionalist mentality dominant in the Spanish intellectual environment, they constitute an unknown and strange body of problems and formulas, which is neither wise nor convenient to engage in. (Sánchez-Mazas 1954, 148) 
In this issue of Theoria, works by Perelman, Braithwaite, Fevrier-Destouches and others can already be found (Ronzón 1992).

Sánchez-Mazas also contributed to this organizational task with introductory submissions on a variety of subjects ranging from the history and philosophy of science and technology to the history and philosophy of logic, including cultural, political and social content, which were always penetratingly scrutinized. In 1955 he won the CSIC Menéndez Pelayo Award for his work Mathematical Foundations of Formal Logic (Sánchez-Mazas 1963), which only managed to get published eight years later in Venezuela thanks to the intervention of the prestigious Spanish philosopher García-Bacca, in exile in the Latin American country, after Sánchez-Mazas was arrested during the 1956 university protests for freedom in Spain.

However, the essence of his existence was marked by the Leibnizian challenge of constituting a universal, arithmetic, complete and consistent Characteristic in order to obtain a perfect representation of complete notions. Sánchez-Mazas devoted his entire research life to meeting this challenge by designing an arithmetic representation of concepts and properties. He himself briefly summed up the essence of his arithmetization program as follows:

In this updated arithmetic representation, after switching from the algebra of an integer's divisors to the numerical Boolean algebra of a positive rational number's binary components lower than 1 , it is possible to arithmetically represent each universal or individual property or concept (respectively, each proposition) of a denumerable finite or infinite system of intensional relations with a rational number in the semi-open interval $[0.1[$, written in hexadecimal, this number being invariant for the class of equivalence to which the property or concept (respectively, proposition) belongs. (Sánchez-Mazas 1996a, 21)

It was both an elementary and highly difficult program at the same time, and the chance to test its skill at performing manual numerical calculations. The emergence of computer resources - even though Sánchez-Mazas always made limited use of them- boosted the development of his program considerably. The applications that Sánchez-Mazas himself developed from his method of arithmetic representation of intensional relational systems covered a diversity of domains, from the non-quantified and quantified logic of von Wright's properties to the geometry of flat and convex polygons and, above all, to normative systems, as will be discussed later in section 4 .

His $\mathrm{PhD}$ thesis from the University of Neuchâtel, Calculation of Norms, defended in 1973 before a panel chaired by Kalinowski, had already become a classic work on the logic of normative systems (Sánchez-Mazas 1973).

He was a lecturer at the University of Neuchâtel for a decade, and was appointed Full Professor at the University of the Basque Country in 1982, going on to become Head of the Department of Logic and Philosophy of Science in Donostia-San Sebastian, where, once again, he began to show his talent as a promoter and organizer. He had set up the Center for Analysis, Logic and Legal Informatics (CALIJ) in 1978, whose aim was to promote research that would bring logicians, linguists, legal philosophers and computer scientists together. Having recovered from a serious illness, he resumed publication of Theoria in its latter period in 1985 . He led research projects on Leibniz's logic and mathematical work, legal arithmetic models, etc. in which members of the Department of Logic and Philosophy of Science and the School of Law at the University of the Basque Country collab- 
orated. He organized scientific congresses and events such as the biennial International Conference on Logic and Legal Informatics (from 1982 to 1988), structured around the logic-computing-law triad and, as head of the abovementioned department, promoted the creation of an Institute of Logic, which was to provide continuity, forty years later, to the direction he had sought at the Luis Vives Institute, where he first started out.

At the same time, this period was particularly productive in terms of his own research activity. Indeed, it was during this period that Sánchez-Mazas most successfully applied his arithmetization method, which he would always use attributively as an updated Leibnizian strategy. It is true that he permanently fed on Leibniz's algorithmic programmatic idea. Nonetheless, his contribution was rigorously personal and integrates, alongside his own original results, ingredients that enabled an autonomous reading of his program. Thus, towards the end of his days, he scrutinized the incorporation of Peirce's logic of relations.

The week before his death, the Society of Logic, Methodology and Philosophy of Science in Spain honored Miguel Sánchez-Mazas by naming him an Honorary Member in recognition of his invaluable contribution to the development of logic and philosophy of science in Spain. His contribution was made with a personal attitude based on loyalty and honesty, and with a deeply sarcastic sense of humor. He was always stubbornly committed to the projects he promoted and was slightly authoritarian in the way he led them, which was also undoubtedly due to the era and context in which he lived.

\section{Calculation $=$ Freedom . Sánchez-Mazas' numerical calculation}

Miguel Sánchez-Mazas' path of logic followed a peculiar direction. At first he followed Leibniz's Calculus of arithmetization, assigning natural numbers to individual terms and properties in an intensional logic approach, so-called logic of comprehension in the traditional sense. However, Sánchez-Mazas later changed the term comprehension for "qualities”, whilst always maintaining the intensional approach.

It was a line that did not follow mathematical practice. Indeed, the finitistic works by Hilbert, and others, which gave rise to formal systems with their associated arithmetization, focused on the extensional line with the same approach that science adopted for its own constitution. This accepted a division into primary and secondary qualities, primary being those of length, mass, space, time, force, etc..., that is, those qualities that were quantifiable, mathematical. Secondary qualities such as color, taste, smell, texture, were considered subjective qualities, specific to each individual, and thus abandoned in scientific practice. They were, nevertheless, basic for ordinary life. However, they were "qualities", not "quantities". And formal logic, or the logic of formal systems, followed the line of quantities - the extensional approach.

The Leibniz-type intensional approach proved to be an impossible dream because of its failure to account for Boolean operators, which Couturat would stress greatly at the beginning of the 20th century. Meanwhile, in the extensional approach, when an attempt was made to arithmetize formal systems, there were absolute limitations that canceled out Hilbertian optimism. Gödel's incompleteness theorems and Türing's undecidability theorems revealed the internal limitations of formal systems with their intended arithmetization.

Despite being aware of all these limitations, and yet radically optimistic, Miguel Sánchez Mazas took the plunge and chose the line of comprehension, following Leibniz 
very closely. However, with its nuances because, to Sánchez Mazas, arithmetization meant more than a simple exercise in mathematical logic. It meant materializing a dream, the dream the Enlightenment thinkers shared; exercising reason, because it was reason that set us free and each individual's freedom implied freedom for all in a world here and now, not in an earthly paradise, as Descartes put down to express his belief that such freedom could only be gained in a world that was paradise... In response to Cartesian skepticism, d'Alembert proclaimed mathematical reason as the key to achieving such a world here and now. And it was in this line, with this optimism, where Sánchez Mazas stood: the search for a numerical characteristic enclosed, in its very construction, the desire to materialize each individual's freedom - freedom in a world here and now.

Sánchez Mazas did so in full knowledge of the limitations mentioned. Looking back to 1994, he asked the following question:

Is it possible today to create some form of Leibnizian Universal Numerical Characteristic that is both consistent and complete, in addition to being flexible and versatile, and which, while recognizing inevitable limitations in its structure and scope - including those derived from the internal limitations of formalisms-, can be applied in a simple and practical way to different logical, scientific and philosophical spheres and systems, providing them with an instrument that is easy and simple to handle, using not only a computer but also manually? (Sánchez-Mazas 1994, 421)

This was a question which, of course, was purely rhetorical. Being aware of the internal limitations of formalism, of the criticism directed at Leibniz's dream by Couturat, would not dispel Sánchez Mazas' optimism. Aware of the fact that universal arithmetization, that the whole of thought, was not possible, that it was not possible to uphold, point blank, Reason $=$ Calculation equality, he found that a limited numerical characteristic was feasible that could be applied to certain branches of knowledge. Moreover, possible progress could be made with regard to formal systems in the sense that they could be decidable in these fields, especially in the modal field and, in particular, in the Calculation of Norms, in first instance, so as to later attempt the decidable arithmetization in fields such as the most complicated ones in jurisprudence.

There were, in these first attempts, certain limitations which were indicated and insisted on by Couturat. Leibniz-type arithmetization was performed using separate, individual concepts, taken one by one with no apparent connection with the others. The concepts were approached in a finite way with an absence of initial internal structuring of what was to be arithmetized. This structuring, for Leibniz, was determined by the context in which these concepts were found at any given time. It was, however, a purely subjective context, with no formal structuring whatsoever. A line of work in which it was not possible to arithmetize an operator such as negation, for instance. These first attempts can be found in some of the essays that Sánchez-Mazas published between around 1951 and 1963 and collected in the first volume of his Selected Works (Sánchez-Mazas 2002)3.

3 All of Miguel Sánchez-Mazas' scientific work can be found referenced in (Sánchez-Mazas 1996c). The author prepared a list of all his scientific, political, social and economic publications two years earlier, which appeared in (Sánchez-Mazas 1996b). 
In a process of constant refinement, from this point on the approach was inverted: now each concept was not considered in isolation but as a whole system $S$ of contents, of "qualities" (or Monadic predicates) that were expressed in concepts or propositions. System $S$ was what would now be taken into account, in its entirety, no longer just of propositions or isolated concepts, but these concepts and their functional relations would now be considered the domain of the numerical representation function; $S$ could be denumerably finite or infinite. Moreover, the set of destination for this function of representation was not the natural number but the semi-open interval of the rationals $[0,1[$, whereby each original element's image was a rational number. Moreover, representation of the image element was not performed in traditional decimal but in hexadecimal, the image element being an invariant number for the class of equivalence with which the concept (proposition) was associated, for the original class of equivalence in the constructed application. In this sense, a negative power of 2 in hexadecimal was made to correspond to each concept (proposition) in system $S$ as a characteristic number, which was its binary development. All this involved arithmetization in rational numbers in binary representation, rather than in natural numbers as had always been done, even in the Gödelian version, where it was no longer meaningful to adopt an isolated concept or proposition.

This constituted a truly epistemological inversion that allowed Sánchez-Mazas to demonstrate all his imaginative capacity in his research process. It was an inversion that, of course, had its ontological and methodological repercussions. This was so despite the fact that he claimed, perhaps with a touch of modesty, that his work was simply "updating" Leibniz's work. However, rather than updating, it was a truly innovative creation because it enabled him to answer the rhetorical question raised above; to answer the possibility raised by Leibniz of obtaining a numerical characteristic even though it was not universal but now limited to partial systems of knowledge. It constituted the solution to the difficulties pointed out by Couturat in 1901 when he insisted on the failure of Leibniz's program because the intensional approach proved to be refractory to arithmetization. Couturat's texts and criticisms feature in many essays by Sánchez-Mazas; in particular, in the highly rich footnotes where the original text is sometimes duplicated, as in (Sánchez-Mazas 1977) or in (Sánchez-Mazas 1991).

He acknowledged the success of this program by writing shortly before his death:

This success is the result of a long and exciting process of successive attempts and discoveries, in different directions and using different methods; more precise, more general and simpler by the day... (Sánchez-Mazas 1996d, 435 footnote 2; Sánchez-Mazas 2002, 451, footnote 2)

This approach was not always envisaged by the author but, with its ups and downs, slowly and steadily took shape, particularly in the aforementioned (Sánchez-Mazas 1991) contribution and his subsequent works, which led to its definitive formulation in (1994) and (1996d).

On the basis of this inversion, he managed to represent the negation operator applicable to concepts (propositions) numerically, which had not been achieved by Leibniz, as Couturat repeatedly pointed out. To do so, first of all, he constructed the "impossible" concept, which was determined by the minimum common multiple of all the characteristic numbers associated with the concepts in system $S$. This number was the maximum or hypersaturated number. Next, the number associated to the negation of a concept or prop- 
osition was determined as the quotient of the hypersaturated number by the characteristic number of the concept (proposition) concerned.

Similarly, he obtained the representation of the combination of concepts (or conjunction of propositions) by means of the least common multiple of the characteristic numbers, rather than doing so by means of the product of prime numbers as was usual. As a dual, the greatest common divisor represented the concept alternative (propositional disjunction).

Thus, the intensional arithmetic representation ceased to be the Boolean algebra of a number's divisors and became the numerical algebra of a number's binary components. It was a conceptual inversion allowing the arithmetization of systems that may have had an infinite number of variables, thereby breaking away from the strict finitism associated with intensional arithmetizations.

Based on these achievements, Sánchez Mazas focused on the arithmetization of fields such as the following: The non-quantified and quantified logic of von Wright's properties; Alethic modal logic (S5); Aristotelian (excluding impossible or empty properties) and modern (including such properties) syllogistics; von Wright's first-order deontic logic; convex plane polygon geometry; normative systems (complete or incomplete, consistent or inconsistent) of positive law.

This last domain allowed him to fulfill another of Leibniz's dreams: the search for clarification and ordering of legal concepts. A field that Sánchez-Mazas named "Ars Judicandi Program” (see, in particular, Sánchez-Mazas 1985-86), to which he devoted his efforts from 1972 onwards. This clarification and ordering would enable the application of arithmetization and, consequently, arithmetic models that could be computerized. In this line, he created the programs "Calculus Rationator II" and "Calculus Consequentiarum II", conceived and developed for computers, including pocket computers. It was a goal that he managed to fulfill in practice, and in an effective way. Volume II of his Selected Works (Sánchez-Mazas 2003) focuses precisely on Sánchez-Mazas' works in the fields of law and computing.

These projects in the field of legal informatics have aroused the interest of Italian authors such as Antonio A. Martino, Gilberto Dini, Carlo Biagoli, Costantino Ciampi and others, resulting in the computerization of sections of the Italian Civil Code.

The application of methods and techniques for logical and mathematical analyses should not be spurned if minimal legal-legislative rationalization is to be gained, whilst being fully aware that such possible computerization does not, in any way, replace legislators, judges or jurists. Sánchez Mazas insisted on this fact, and even wrote: "Let us give the logician what belongs to the logician, and the judge what belongs to the judge" (Sánchez-Mazas 1985-86, 800; Sánchez-Mazas 2003, 350).

It was a way of recognizing, albeit implicitly, that a Calculation could not simply be identified by Reasoning, by thought. Such impossibility of identification became increasingly evident in Sánchez-Mazas' ever-enriched conceptual evolution. In an authentically conceptual mathematical work, not only is there purely mechanical calculation or deduction; there is always inventiveness, constructive imagination.

Sánchez-Mazas' constructive imagination was combined with a passion that revealed his radical optimism and connected with a kind of mysticism of numbers in all aspects of life. On the basis of this optimism, the universe was approached as if it were written in mathematical terms - geometric and arithmetic terms, differential equations in partial de- 
rivatives, algebraic structures and so forth. It was this conviction and constructive optimism that Sánchez-Mazas shared with many other creative mathematicians.

Mathematical language not only enables us to describe and comprehend, to decipher the universe but also, thanks to mathematics, the mathematician gets to live in a world of freedom and justice. A world longed for and passionately desired by Sánchez-Mazas; a world that goes far beyond the conceptual domain; a fanciful world which is the embodiment of freedom and justice. Leibniz's Let us Calculate $=$ Let us Reason became, for Sánchez-Mazas, Let us Calculate $=$ Freedom, Justice.

A dream, Miguel Sánchez-Mazas' dream, extremely difficult to fulfill in this world, as he saw for himself when he became a victim of the injustices he encountered, always optimistically, with "love". In one of his last works, he wrote: "My Italian and Spanish blood both tell me that the universe and the human spirit are, in addition to numbers, also freedom and, above all, love.” (Sánchez-Mazas 1996a, 31)

\section{REFERENCES}

Cutanda, María Luisa (2019). Breve biografía de Miguel Sánchez-Mazas. https://fpabloiglesias.es/entrada-db/6130_sanchez-mazas-ferlosio-miguel/

Echeverría, Javier, de Lorenzo, Javier, Peña, Lorenzo (eds.) (1996). Calculemos... Matemáticas y libertad [Homenaje a Miguel Sánchez-Mazas]. Madrid: Trotta.

París, Carlos (1996).Pequeña semblanza de Miguel Sánchez-Mazas en el aniversario de su muerte, Theoria, 11(26), 5-11.

Ronzón, Elena (1982-83). La revista Theoria y los orígenes de la filosofía de la ciencia en España. El Basilisco No. 14, julio 1982-febrero 1983, 9-40. Reprinted in Theoria 1992, 7 (16-17-18), vol. A, 591-622.

Ronzón, Elena (1992). Algo más acerca de "Theoria”, e Índices (1952-1955). Theoria, 7 (16-17-18), vol. A, 623-644.

Sánchez-Mazas, Miguel (1954). Presentación de la Sección de Lógica. Theoria, 3(7-8), 148.

Sánchez-Mazas, Miguel (1963). Fundamentos matemáticos de la lógica formal. Caracas: Universidad Central de Venezuela, Instituto de Filosofía.

Sánchez-Mazas, Miguel (1973). Calculo de las Normas. Barcelona: Ariel.

Sánchez-Mazas, Miguel (1977). Un modèle mathématique de la logique peut-il se fonder sur l'intension? Actes de la Société helvétique des sciences naturelles, Bern, 361-387 (Sánchez-Mazas 2002, 181-202).

Sánchez-Mazas, Miguel (1985-86). Le Programme 'Ars Judicandi'. Theoria, 1(3), $779-817$ (Sánchez-Mazas 2003, 321-364).

Sánchez-Mazas, Miguel (1987). Fundación de un nuevo centro: Se renueva el Instituto de Filosofía del C.S.I.C. en Madrid. Theoria, 2(4), 240-244.

Sánchez-Mazas, Miguel (1991). Actualisation, développement et perfectionnement des calculs logiques arithmético-intensionnels de Leibniz. Theoria, 6 (14-15), 175-259 (Sánchez-Mazas 2002, 295-346).

Sánchez-Mazas, Miguel (1994). Actualización de la Característica numérica universal de Leibniz. (Foreword by Javier de Lorenzo). Cuadernos de Theoria, No. 1. San Sebastián: CALIJ (Sánchez-Mazas 2002, 421450).

Sánchez-Mazas, Miguel (1996a). “Calculemos...” Matemáticas y libertad. In Echeverría, de Lorenzo, Peña (eds.) 1996, 13-31.

Sánchez-Mazas, Miguel (1996b). Bibliografía de y sobre Miguel Sánchez-Mazas. In Echeverría, de Lorenzo, Peña (eds.) 1996, 33-54.

Sánchez-Mazas, Miguel (1996c). Miguel Sánchez-Mazas. 50 años de actividad científica (1946-1996). Theoria, $11(26), 13-25$. 
Sánchez-Mazas, Miguel (1996d). La aritmética intensional: un cálculo numérico universal de significados, contenidos y cualidades. In Echeverría, de Lorenzo, Peña (eds.) 1996, 389-449.

Sánchez-Mazas, Miguel (2002). Obras Escogidas. Vol I. Concepto y número. La característica numérica universal. Ed. Javier de Lorenzo. Leioa: University of the Basque Country Press.

Sánchez-Mazas, Miguel (2003). Obras Escogidas. Vol II. Lógica, Informática, Derecho. Eds. Gabriel Painceyra and Javier de Lorenzo. Leioa: University of the Basque Country Press.

Javier de Lorenzo, mathematician and philosopher, is Professor Emeritus at the University of Valladolid. He has recently published Matemática e Ideología. Fundamentalismos matemáticos del siglo xx (Plaza y Valdés, 2017), Un mundo de artefactos. Breve historia de la ciencia y la técnica (Trotta, 2020). He was in charge of the edition of Miguel Sánchez Mazas' Selected Works (the second volume together with Gabriel Painceyra) published by the University of the Basque Country in two volumes (2002 and 2003).

E-maIL: javierdelor@gmail.com

Andoni Ibarra is the head of the Miguel Sánchez-Mazas chair at the University of the Basque Country, a chair devoted to Science, Technology and Innovation Studies, and is also editor-in-chief of Theoria. His main areas of research are scientific practices and the relationship between science and society.

Address: Dpt. of Logic and Philosophy of Science, HEFA 1, Tolosa Hiribidea 70 (20018 Donostia). E-mail: andoni.ibarra@ehu.eus 